\title{
Přetrvávající primární reflexy u dětí předškolního a mladšího školního věku a jejich vliv na edukaci
}

\section{Persistent Primary Reflexes in Preschool and Early School Children and their Impact on education}

\author{
Petra Bendová, ÚPPSP PdF UHK, Hradec Králové
}

\begin{abstract}
Abstrakt
Text příspěvku seznamuje s problematikou přetrvávajících primárních reflexư u dětí předškolního a mladšího školního věku, přičemž poukazuje na př́mou souvislost mezi přetrvávajícími primárními reflexy a obtížemi na úrovni vývoje řeči, jenž následně ovlivňuje proces edukace těchto jedinců. V konkretizované podobě popisuje problémy, s nimiž se děti predškolního a mladšího školního věku s přetrvávajícími primárními reflexy setkávají v průběhu edukace. Jedná se zejména o problémy na úrovni vúvoje řeči, narušení koncentrace pozornosti, poruchy učení, obtíže spojené se sníženou kvalitou hrubé a jemné motoriky, koordinace pohybů a grafomotiriky, jakož i v oblasti senzomotorické integrity vjemů, jež negativně ovlivňují optimální průběh edukace těchto dětí. V závěru textu je poukázáno na možnosti intervence eliminující projevy a důsledky přetrvávajících primárních reflexů u dětí predškolního a mladšího školního věku.
\end{abstract}

\section{Klíčová slova}

přetrvávající primárníreflexy, edukace, dítě,předškolnía mladšǐškolní věk, speciální vzdělávací potřeby,intervence

\section{Abstract}

The text introduces the issue of persistent primary reflexes in children of preschool and early school age, pointing to the direct link between persistent primary reflexes and difficulties at the level of speech development, which subsequently affects the process of education of these individuals. In a concrete form, it describes the problems that children of preschool and younger school age with persistent primary reflexes encounter during education. These include speech development problems, impaired attention, learning disabilities, difficulties with reduced quality of gross and fine motor skills, coordination of movements and graphomotirics, as well as sensorimotor integrity of perceptions, which negatively affect the optimal course of education of these children. At the end of the text, the possibilities of intervention eliminating the manifestations and consequences of persistent primary reflexes in children of preschool and younger school age are pointed out.

\section{Keywords}

Persistent Primary Reflection, Education, Child, Preschool and Early School Age, Special Learning Disabilities, Intervention

\section{Úvod}

Psychomotorický vývoj dítěte je složitým procesem. Rychlost a kvalita vývoje psychomotorických dovedností každého jedince je ovlivněna celou řadou biologických i sociálních faktorů. Prokazatelný je vliv postupného rozvoje postury, rovnováhy, svalové síly, orientace, koordinace pohybů. Ty vycházejí ze základních stádií vývoje jedince směrem kefalokaudálním (fixace hlavy ovlivňuje stabilizaci posturálních svalů trupu - držení těla a koordinaci pohybů), proximodistálním (stabilizace osového skeletu umožňuje rozvoj pohybů vycházejících z ramenního a kyčelního kloubu směrem k periferním částem těla - rozvoj jemné motoriky) a ulnoradiálním (umožňujícím rozvoj aktivního úchopu směrem od malíkové strany ke straně 
palcové). (IIIingworth, 2012) Standardně vyvíjející se jedinec by měl všemi těmito stádii projít. Pokud však u dítěte přetrvávají některé z primárních reflexů, působí jako blokátor přirozeného vývoje dítěte, což se negativně projevuje nejen do oblasti rozvoje hrubé a jemné motoriky, ale i koordinace pohybů, rozvoje řeči, grafomotoriky a sekundárně je tak negativně ovlivněna kvalita a efektivita preprimární a primární edukace dětí s přetrvávajícími primárními reflexy (dále pouze PPR), ale i jejich aktivizace a motivace v oblasti edukace. Prezentovaný př́íspěvek dokládá přímou souvislost mezi výskytem PPR a problémy na úrovni řečového vývoje, grafomotoriky, koordinace pohybů a (rizika) specifických vývojových poruch učení u dětí předškolního a mladšího školního věku, a to na základě výsledků výzkumu realizovaného na PdF UHK v roce 2020. V daném kontextu je tedy třeba poukázat na důležitost včasné identifikace dětí s PPR jako jednoho z prostředků prevence vzniku (nejen) školních obtíží u dětí předškolního a mladšího školního věku.

\section{Současný stav poznání a prezentace výsledků výzkumu}

Komunikace je jednou z nejdůležitějších životních potřeb člověka. Komunikace a zejména pak verbální komunikace/mluvená řeč sehrává významnou roli v rozvoji osobnosti člověka, tj. i v průběhu edukace dětí předškolního a mladšího školního věku. Dovednost verbálně komunikovat však není člověku vrozená. Postupně se jí učí. Faktorů ovlivňujících vývoj řeči je celá řada, přičemž za zásadní lze považovat pohybový vývoj dítěte (hrubá motorika, jemná motorika), rozvoj percepce (zrakové, sluchové), kognice (pamět', pozornost, myšlení, IQ), ale i dostatek podnětů ze strany sociálního okolí včetně vytvoření pozitivní emoční vazby k pečující osobě. (Bytešniková, 2012) Tuto skutečnost potvrzují i další realizovaná výzkumná šetření. Např. LeBarton a Iverson (2016 in Volemanová, 2020) prokázali, že motorický vývoj souvisí s rozvojem jak verbálních, tak i neverbálních schopností. Souvislost mezi motorickými a řečovými poruchami zkoumal také Cheng et al. (2009), a to na vzorku 363 předškolních dětí ve věku od 5 do 6 let. S využitím jazykových testů a motorického testu (Movement Assessment Battery for Children, neboli M-ABC) prokázal významnou souvislost mezi výsledky motorického testu a výsledky jazykových testů.

Kvalita psychomotoriky a řeči může být u dětí (ale i u dospívajících a dospělých) limitována aktivitou přetrvávajících primárních reflexů, které ovlivňují rozvoj rovnováhy, koordinace pohybů, svalové síly i orientace. Odlišnosti na úrovni psychomotorického vývoje a perzistujících primárních reflexů lze pozorovat např. u dětí s PAS, ADHD, s narušenou komunikační schopností či specifickými poruchami učení. (Bezděková, 2008) V odborné literatuře se o PPR hovoří dále v kontextu jejich výskytu u dětí s dg. DM. Primární reflexy se mohou objevit v časech odlišných od fyziologického období výskytu jako reflexy reziduální, způsobující narušení psychomotorického vývoje ve formě tzv. neuro-vývojového opoždění (Grzywniak, 2016).

Na základě stávajících poznatků ontogenetického vývoje je známo, že reflexní a motorické vzorce, na jejichž základě pak vznikají další vyšší motorické, kognitivní a behaviorální funkce, mají svá specifická stádia vývoje a zrání. V určitých specifických vývojových obdobích jsou ontogeneticky starší funkce nahrazovány vývojově mladšími. Z těchto poznatků vývojové psychologie a neurofyziologie vyplývá, že některé vývojově starší fáze musí za normálních (zdravých) okolností vývoje a zrání dítěte v jistém období vymizet a být nahrazeny ontogeneticky novějšími formami (Konicarová, 2013).

Primární reflexy (= PR) jsou souborem (ontogeneticky starších) pohybových vzorců u novorozence, které se objevují již během prenatálního období. PR jsou nepodmíněné reflexy vycházející z mozkového kmene, které nevyžadují aktivitu kortextu. Vyvolávají stereotypní, automatické pohyby (McPhillips, 2000). PR by měly být plně rozvinuté již při porodu donošeného dítěte. Primární reflexy pomáhají při porodu, dále napomáhají novorozenci přizpůsobit se novému prostředí mimo dělohu a budovat základ pro motorické a kognitivní dovednosti. Tyto reflexy způsobují změny úrovně a distribuce svalového tonu, které mohou primárně ovlivnit držení těla a pohyb. Tyto reflexy jsou spolu s posturální kontrolou základními vývojovými vzorci (Berne, 2006). Jakmile primární reflex splnil svou funkci (tj. vybudoval specifickou neuronovou cestu), měl by být integrován a inhibován. Integrace a inhibice primárních reflexů je závislá na myelinizaci nervů, což je zase závislé na zrání centrálního nervového systému opakovanou fyzickou reakcí a na interakci s prostředím. Všechny neuronové cesty primárních reflexů musí být myelinizovány, integrovány a inhibovány, aby se mohla vyvíjet hrubá a jemná motorika. (Jager, 2009).

Pohyby vyvolané primárními reflexy pomáhají vytvářet hustou neuronovou sít', která umožňuje propojení různých oblastí mozku, která jsou důležitá pro procesy učení, komunikační schopnosti, emocionální a citové vztahy a motivaci. Jak se vyšší mozková centra vyvíjejí, primární reflexy začínají postupně „překážet“ a musí být inhibovány, aby se mozek mohl vyvíjet neurologicky správným způsobem. (McPhillips, 2000) 
Přetrvávající primární reflexy po 1. - 2. roce věku dítěte způsobují, že se nevytvoří optimální smyslově-motorická cesta (pozn. vzruchy musejí procházet přes nezralý mozkový kmen), což vedek nekontrolovaným a nekoordinovaným pohybům, které musí být vědomě kompenzovány. Přetrvávající primární reflexy mohou také způsobit problémy se zpracováním smyslové informace. Senzorická integrace je schopnost mozku správně zpracovat příchozí podněty a umožňuje člověku vytvářet tzv. adaptivní odpověd. Pokud zpracování senzorické informace neprobíhá optimálně, mluvíme o dysfunkci senzorické integrace, a to souvisí s vývojem nervového systému, což může zpo̊sobovat mj. i problémy s výslovností a řečí. (Jager, 2009).

Primární reflexy vyvolávají pohyby a souhyby a tyto opakované pohyby pomáhají posilovat nervová spojení mezi tělem a mozkem.

Moroův reflex je reakcí novorozence na úlek. Novorozenec ještě neumí správně zanalyzovat bezpečnost/nebezpečnost stimulu, a proto se spustí z mozkového kmene Moroův reflex. Tento reflex se objevuje již v 9.-12. týdnu in uterinního vývoje dítěte, rozvíjí se po celou dobu těhotenství (správně vyvinutý je cca od 28. gestačního týdne věku) a v době porodu je již zcela vyvinutý.

V prvních měsících života Moroův reflex pomáhá dítěti přežít tím, že při úleku (nečekaný pohyb, zvuk nebo např. ztráta rovnováhy vleže na zádech) začíná křičet (= „volá o pomoc“). Tento reflex navíc pomáhá vyvíjet i dýchací mechanismus již intrauterinně. Moroův reflex napomáhá i při prvním nádechu po porodu a tím předchází zadušení v důsledku ucpání dýchacích cest. V základní formě by ale měl být inhibován do 2.-4. měsíce života a postupně nahrazen vyspělým Strauss reflexem. Pokud ale Moroův reflex není inhibován, dítě se projevuje jako přecitlivělé na (některé) senzorické stimuly. Nečekaný zvuk, světlo, pohyb, změna polohy nebo rovnováhy může u tohoto dítěte zaktivovat Moroův reflex, které je tak neustále „ve střehu“. Při aktivaci tohoto reflexu se stimuluje i produkce adrenalinu a kortizolu (= stresových hormonů), které u dítěte zvyšují reaktibilitu a sensitivitu. Děti s přetrvávajícím Moroovým reflexem vnímají svět jako soubor hlasitých a ostrých senzorických stimulo̊, jež na ně působí a odklánějí jejich pozornost od právě realizovaných aktivit. Takové dítě nedokáže odfiltrovat nevhodné stimuly a tím je přetížené (Goddard, 2005).

Dítě s přetrvávajícím Moroovým reflexem se s tím může vyrovnávat většinou dvěma způsoby: bud' bude bojácné, bude raději zůstávat v ústraní, bude mít problémy se přizpůsobit a přijímat a předávat fyzický kontakt; nebo bude naopak hyperaktivní, až agresivní a hodně podrážděné, dítě neumí „číst" (non-verbální) řeč těla a bude chtít mít situaci neustále pod kontrolou. Pokud je dítě s přetrvávajícím Moroovým reflexem v rušnějším prostředí (např. MŠ/ZŠ nebo místnost, kde je puštěná televize apod.), mưže mít problémy s porozuměním, a proto i s osvojením mluvené řeči (a to i na úrovni gramatické struktury řeči a jazyka). (Volemanová, 2019)

Hurst (2006) dokázal, že po inhibici Moroova reflexu děti vykazují významné zlepšení při optometrickém testování zaměřeném na fúzi, akomodaci, okulomotoriku, sledování předmětů očima, sakadické pohyby, fixaci a konvergenci. Vysvětluje to tím, že pohyb zpơsobený Moroovým reflexem stimuluje vestibulární systém. Všechny nezpracované smyslové informace procházejí vestibulárním systémem a cerebellem dříve, než jsou dále zpracovány. Rozpor mezi údaji z vestibulárního systému a mozečku na jedné straně a těch získaných od ostatních smyslových orgánů na straně druhé může mít dalekosáhlé důsledky pro učení. Sluch a vestibulární systém se vzájemně ovlivňují, a tak Moroův reflex nepřímo ovlivňuje vývoj sluchu (Jager, 2009).

Během několika prvních týdnů života začínají děti nejdříve ovládat svaly krku a hlavy. K tomu jim pomáhá primární reflex zvaný tonický labyrintový reflex (TLR). TLR má svůj původ ve vestibulárním orgánu vnitřního ucha. Pokud dítěti zakloníte hlavičku, zvyšuje se tonus v extenzorech v celém těle (dítě se natáhne), a naopak, když dítěti hlavičku předkloníme, zvýší se tonus ve flexorech, dítě skrčí končetiny a zaujme podobnou polohu, jaká je typická pro polohu v děloze, tzv. „flexor habitus“. TLR by měl být zcela vyvinut již při narození. TLR do flexe by měl být inhibován do 4. měsíce věku dítěte, TLR do extenze se inhibuje ale podstatně déle (je spojen s vývojem posturálních reflexů), a proto může být inhibován až kolem 3. roku dítěte (Goddard, 2005). Dítě se ale rychle učí, a tak po prvních šesti týdnech se naučí v poloze na břiše držet zvednutou hlavičku v rovině páteře. Vzhledem k tomu, že vývoj postupuje kefalokaudálním směrem (tzn. postupně od hlavy, přes horní polovinu těla, dolní polovinu těla až k patě), se dítě musí naučit ovládat hlavu dříve, než může získat kontrolu nad zbytkem těla. Tím se dítě naučí kontrolovat polohy hlavy vůči tělu. Tato schopnost je nezbytná pro pozdějšśi udržení rovnováhy, vzpř́mený postoj a koordinaci (Goddard, 2005). Až když se vyvíjí nezávislé pohyby hlavy a končetin (pohyby už nejsou holokinetické), 
bude mít dítě možnost překročit „střed těla“ končetinami, což je nezbytné pro křížové pohyby, přičemž se tím také zlepšuje spolupráce mozkových hemisfér. Pokud se inhibuje činnost přetrvávajícího TLR, můžeme dosáhnout vyšší úrovně posturální stability, tím získá dutina ústní volnost pohybu s účinným a přesným funkčním pohybem (Gangale, 2004). Dítě s přetrvávající TLR nemůže, pohybovat jen jednou rukou nebo nohou, to znamená, že když se dítě dívá dolů, často pokrčí nohy v kolenou a jde mírně trupem dopředu. Když si stoupne na jednu nohu, nejraději by pokrčilo i druhou nohu a bude se muset velice soustředit na to, aby nechalo druhou nohu nataženou. Pro dítě s přetrvávajícím TLR může být těžké lézt po čtyřech, protože extenze (záklon) hlavy způsobuje současně extenzi nohou. (Volemanová, 2019). Je třeba připomenout, že lezení a plazení je velice důležité pro vývoj správné koordinace ruka-oko a pro integraci vestibulární informace s informacemi z ostatních smyslových orgánů. Dítě může mít horší rovnováhu ve stoji i proto, že pokaždé, když pohybuje hlavou v předozadním směru, je ovlivněn svalový tonus. K tomuto problému ale dochází i v sedu. Pokud takovéto dítě při čtení sedí (má hlavu v mírném předklonu), ovlivňuje to jeho svalový tonus tak, že se zvýší tonus ve flexorech, a tak po chvilce sedí s kulatými zády, podpírá si hlavu nebo si dokonce lehne na stůl. Další možnost kompenzace TLR je, že si dítě sedne na (nebo mezi) paty. Má-li dítě mluvit zřetelně a koordinovaně, musí přesně používat malé svaly, které ovládají čelisti, rty a jazyk. Děti, které mají nižší svalový tonus (např. v důsledku přetrvání TLR), se potýkají s obtížemi při rozvoji síly a stability proximálních svalů. Tyto svaly jsou také základnou, na níž se rozvíjejí jemné pohybové dovednosti ruky (Kurtz, 2015).

Přetrvávající TLR způsobuje tedy horší držení těla, dítě hlavu často drží v předsunuté poloze, čímž dochází k většímu napětí týlového svalstva. Kvůli trvale většímu napnutí týlového a krčního svalstva může dojít k podobným jevům jako při cervikálním syndromu. Hlavní zátěž je zde ovšem ve svalstvu, nikoliv primárně v nervové oblasti. Přetrvávající TLR může způsobit různý svalový tonus a zapř́ičinit kolísání svalové kontroly (ovládání) při vykonávání orálně-motorických pohybů v průběhu mluvení a polykání(Volemanová, 2019).

Pokud se inhibuje činnost přetrvávajícího TLR, můžeme dosáhnout vyššśí úrovně posturální stability, tím získá dutina ústní volnost pohybu s účinným a přesným funkčním pohybem. Abychom toto dosáhli, je třeba nejdříve zajistit stabilitu ramen a trupu. Ramena a spodní partie těla slouží jako kotva, která tvoří základnu pro pohyb obličeje, protože ramena stabilizují čelist a čelist stabilizuje jazyk (Gangale, 2004).

Lze konstatovat, že prozkoumáváním okolního prostředí je dítě vystaveno vjemům, jež působí na všechny smysly. Jsou to zrakové, sluchové, hmatové, chutové a čichové vjemy, ale také vjemy specifické pro ovládání hrubé motoriky, včetně vestibulárních a proprioceptivních vjemů. Pokud dítě pocit́uje smyslové vjemy při pohybových činnostech, mozek tyto informace zpracovává a rozhoduje, jak by na ně tělo mělo reagovat, potom vyšle signály k př́slušným svalům a tělo se dá do pohybu. Z tohoto hlediska je smyslová zpětná vazba, jež se objevuje při pohybových činnostech, důležitým faktorem v procesu motorického učení (Kurtz, 2015). Rozvíjení hrubých motorických dovedností se neobejde bez častého procvičování a opakování. Děti, které nemají rády pohybové činnosti, nebo nemají možnost pohybu (neustálé nošení, sezení v autosedačce nebo ležení na měkkém polštáři), nebo mají při pohybu nepříjemné a matoucí smyslové vjemy, prozkoumávají své okolí s menším zájmem a mají tím pádem méně cviku při rozvíjení pohybových dovedností. Vývoj motoriky (od zvedání hlavy přes plazení a lezení až po chůzi) ovlivňuje vývoj mozku. Např́klad během fáze lezení se hodně stimuluje myelinizace v CNS (hlavně corpus callosum). (Bilo in Volemanová, 2020) To je důležité pro dobrou spolupráci mozkových hemisfér. Řeč a mluvení jsou koordinovány centry na různých místech v mozku. Spolupráce těchto oblastí je tedy klíčová. Nedostatky v synchronizaci mezi hemisférami vedou k obtížím s porozuměním, prováděním a dokončením aktivit každodenního života. Správné držení hlavy poskytuje rovnovážnému ústrojí referenční bod, ze kterého může rovnovážné ústrojí usměrňovat ostatní smyslové orgány a svalové skupiny. Pokud dítě nemá stabilní referenční bod, ovlivňuje to spolupráci s ostatními smyslovými orgány. Tonický labyrintový reflex spolu s horší rovnováhou způsobuje horší vnímání těla a prostoru, cožje předpoklad pro orientaci v prostoru (co je vpravo-vlevo, nahoře-dole, vepředu-vzadu) a v čase (dnes, včera, zítra, za hodinu...). (Goddard, 2005) Hrubá motorika se nejrychleji rozvíjí v prvních dvou letech života, ale nepřestává se zlepšovat a automatizovat do dospělosti. Dovednosti, které tvoří komplex hrubé motoriky, jsou považovány za základ mnoha vyšších schopností souvisejících s učením a chováním (Kurtz, 2015).

V návaznosti na vývoj hrubé motoriky probíhá také vývoj dítěte v oblasti motoriky jemné, jež zahrnuje všechny pohybové aktivity prováděné drobnými svalovými skupinami, zejména rukou, ale i úst či nohou, vyžadující přesnost při plnění motorického úkolu (Vyskotová et al., 2013). 
Nejrychleji se jemná motorika rozvíjí v raném dětství, přičemž se zlepšuje až do dospělosti. Vývoji jemné motoriky ruky předchází vývoj vidění, to znamená, že dítě se nejdříve naučí dívat/vnímat zrakem a zkoumat předměty očima, až poté začne zkoumat rukama. Propojení mezi zrakem a jemnou motorikou souvisí se zapojením asymetrického tonického šíjového reflexu (ATŠR), s jehož podporou dítě cvičí první koordinaci ruka-oko. Asymetrický tonický šíjový reflex je aktivován, když pasivně otáčíme hlavu na jednu nebo na druhou stranu. Tam, kam otočíme hlavu se paže i noha extendují, zatímco druhá paže i noha (kontralaterální) se naopak flektují s vnitřní rotací. Dítě tedy při otočení hlavy extendovat paži a očima sledovat prsty na ruce, což napomáhá postupnému rozšiřování schopnosti dítěte zaostřit zrak na délku paže. ATŠR podporuje také i první pokusy dítěte dosáhnout na věci. Nejdříve se dítě dívá na svoje ruce nevědomě, ale postupně lépe zaostří zrak na svoje ruce a sleduje předměty. Jinými slovy, ATŠR poskytuje první trénink koordinace ruka-oko. (Goddard, 2005) ATŠR by měl fyziologicky vyhasnout cca do 3. měsíce věku dítěte. (Volemanová, 2019)

U dítěte s aktivním ATŠR je tělo imaginativně rozděleno (z hlediska vnímání osy těla) na dvě poloviny - na pravou a levou, přičemž spolupráce mezi oběma polovinami mozku je minimální a „překročit“ pomyslnou střední čáru těla je velice těžké (Grzywniak, 2016). Proto kdybychom např́iklad chtěli po předškolákovi, aby hračku, kterou má v pravé ruce, položil na levou stranu stolu, pravděpodobně přenese pravou ruku na střed těla, tam přendá hračku do levé ruky a teprve pomocí této druhé ruky položí hračku na stůl (pozn. nenapadne položit pravou rukou hračku rovnou na levou stranu stolu, nebo se otáčí celým trupem, než aby rukou překročil střední čáru těla) (Volemanová, 2019).

Spolupráce mozkových hemisfér je ale důležitá také pro řeč/rozvoj řeči. Na produkci řeči se podílejí i centra uložená v prodloužené míše, mozečku a mezimozku. Z mezimozku se řídí např. činnost hlasivek, melodie a hlasitost mluvy, její frázování, tj. vesměs řečové složky mimo vlastní artikulaci. Kdysi se soudilo, že centra řeči jsou uložena ve vedoucí hemisféře mozku, ale ani to není jednoznačné, na řeči, tak jako na jiných intelektuálních činnostech, se podílí vlastně celý mozek, i když různou měrou. Proto horší spolupráce mozkových hemisfér může způsobovat problémy od poruch řeči až k poruchám učení. Často v takových případech vidíme také nesoulad mezi mluveným a psaným projevem. (Krčmová, 2016 in Volemanová, 2020)

U dětí s TLR se můžeme setkat také s přetrvávajícím hledacím reflexem (pozn. ten by měl vymizet kolem 3. měsíce života), sacím/polykacím reflexem (pozn. koordinace sání s polykání spolu s příjmem potravy a dýcháním nastupuje po 32. týdnu těhotenství, kolem 5.-6. měsíce vymizí), kousací reflex (pozn. lze ho pozorovat do 7. měsíce věku dítěte, kdy je vystřídán vědomým kousáním), dávivý reflex (pozn. přetrvává celý život a má ochrannou funkci). Uvedené reflexy by v případě svého přetrvávání brzdily aktivní a záměrné řízení příjmu potravy a řeči. (Stará, 1996). Pokud sací reflex přetrvává déle, než je fyziologické, mohou vznikat problémy tím, že poloha jazyka zůstává př́liš vpředu v ústech, což způsobuje problémy s mluvením a polykáním. U dětí se proto může vyskytovat hypersalivace, ústa mohou být trochu pootevřená, retní uzávěr není dostatečný. Děti s přetrvávajícím hledacím a/nebo sacím reflexem často vyhledávají orální stimulaci (pozn. potřebují něco žvýkat nebo sát, a tak dlouho cucají palce, vlasy, tužky, límečky apod., nebo naopak nemají rády různé konzistence jídla a jsou citlivější kolem úst). U těchto dětí se setkáváme také s obtížemi na úrovni artikulace a s držením hlavy v předsunuté poloze (podobně jako je tomu u dětí s přetrvávajícím TLR). (Volemanová, 2019)

V roce 2020 byl na UHK realizován výzkum zaměřený na identifikaci přetrvávajících primárních reflexů u dětí s narušenou komunikační schopností (dále pouze NKS) (včetně rizika vzniku specifických poruch učení a chování) a specifických poruch učení a chování předškolního a mladšího školního věku.

Za participace pedagogů mateřských a základních škol z celé ČR (pozn. jednalo se o studenty kombinované formy studia Učitelství pro MŠ Bc. a Mgr. PdF UHK) proběhlo testování skupiny 100 dětí předškolního věku s NKS a 100 dětí školního věku s NKS a SPU.

K testování bylo využito dvou testů na propriorecepci a rovnováhu a dále pak sedmi testů sledujících výskyt PPR, tak jak byly prezentovány na kurzu lektorovaném Mgr. Marjou Volemanovou „Pohybem se učíme - Neuro-vývojová stimulace ve školní praxi“ (2019) a publikovány v podpůrném materiálu pro realizaci tohoto kurzu.

K etice výzkumu je třeba podotknout, že testování dětí proběhlo na základě písemného informovaného souhlasu zákonných zástupců vybraných dětí. Data/podklady získaná/é výzkumem byla/y po jejich vyhodnocení skartovány. Aktuálně jsou k dispozici anonymizované přehledy sumarizovaných dat vyplývají- 
cích z analýzy výsledků testů, jež neveřejně archivuje řešitelka výše prezentovaného výzkumu Dr. Bendová.

Cílem prezentace dat/výsledků v rámci tohoto textu není seznámit s detailním přehledem výskytu jednotlivých PPR u dětí s NKS a rizikem SPU předškolního věku a s PPR u dětí/žáků s NKS školního věku a se SPU, ale uvést komplexní sumarizaci výsledků zkoumaného vzorku.

Z analýzy dat vyplývá, že u skupiny dětí předškolního věku (pozn. jednalo se o 100 dětí s diagnostikovanou NKS - opožděný vývoj řeči, dyslálie, specificky narušený vývoj řeči = vývojová dysfázie, balbuties + s identifikovaným rizikem vzniku SPU, jenž byl zpravidla spojen také s diagnózou dyslálie, verbální dyspraxie či minimálně s artikulačními obtížemi) se PPR vyskytovaly u 87 (= 87\%) dětí tvořících výzkumný vzorek (tzn., že se u 87 dětí vyskytl minimálně jeden PPR).

U dětí mladšího školního věku tvořícími výzkumný vzorek, tj. u skupiny 100 dětí s diagnostikovanými SPU a NKS = dg. dyslálie + specificky narušený vývoj řeči = vývojová dysfázie) byly PPR zjištěny u 82 (= u 82 \%) dětí/žáků ZŠ.

Lze tedy konstatovat, že u obou skupin je výskyt PPR poměrně vysoký a lze tedy předpokládat, že specifičnost obtíží na úrovni komunikace (NKS) a vyskytujícího se rizika SPU a již diagnostikovaných SPU je do určité míry zcela jistě podmíněna neutlumením PPR v postnatálním období a bylo by vhodné u těchto dětí zahájit intervenci směřující k utlumení perzistujících PPR.

Tato komplexně prezentovaná zjištění lze doplnit např. i o závěry zahraničního výzkumu, který v roce 2017 realizoval Bilbilaj (in Volemanová, 2020), jenž v konkretizované podobě identifikoval přetrvávající PPR, a to palmární, TLR, sací a hledací reflex, u 71,4 \% dětí s opožděným vývojem řeči (OVŘ).

\section{Závěr}

Z výše uvedeného vyplývá, že rozvoj hrubé a jemné motoriky lze považovat za základ i pro rozvoj řečové komunikace. Komunikaci lze současně považovat za nástroj optimálního průběhu edukace a socializace dětí předškolního a mladšího školního věku. Z tohoto důvodu je třeba věnovat pozornost jakýmkoli odchylkám na úrovni psychomotorického vývoje dítěte a sledovat i jeho projevy v oblasti verbální (ale i neverbální komunikace). V případě, že pedagogové (popř. logopedi) registrují u dětí/žáků//klientů/pacientů problémy na úrovni motorické a komunikační, měli by dokázat na základě projevů zjistit, co je jejich př́činou. K tomu slouží specificky orientované vyšetření přetrvávajících primárních reflexů. Na základě identifikace PPR je vhodné zahájit intervenci v podobě speciálních cvičení, jež vedou k inhibici PPR. Za tímto účelem se v Č́R nejčastěji využívá Neuro-vývojová stimulace (= NVS) a Neuro-vývojová terapie (NVT), která kromě fyzioterapeuticky orientované inhibice PPR využívá také prvky speciálně-pedagogické a začleňuje senzomotorickou integraci. NVT je využitelná ve věkové kategorii 3-4 letých dětí, lze ji však aplikovat i u dospělých. Terapie spočívá v realizaci jednoduchých cviko̊, které často napodobují pohyb vyvolaný primárními reflexy, a to pro to, aby se vyvinula správná propojení v mozku díky nimž, bude mozek sám schopen tyto reflexy postupně inhibovat. Aktivita PPR je tedy cvičením přirozeně potlačena, a tím zmizí i související psychomotorické obtíže. Ve speciálněpedagogické praxi je využívána NVS. Jedná se o program, který vychází z NVT. NVS je vhodná hlavně pro (speciální) pedagogy, (klinické) logopedy a jiné odborníky, kteří pracují s dětmi s poruchami učení, chování a komunikace. V podstatě se jedná o soubor čtyř cviků, jež mají cílit na zkvalitnění rovnováhy (1x), inhibování PPR (2x) a relaxaci či senzorickou integraci (1x), které jsou realizovány v průběhu 25. týdnů. Cvičení jsou koncipována tak, aby ti kdo je v praxi s dětmi s PPR realizují nemuseli mít fyzioterapeutické vzdělání (tj. zásadní dílčí poznatky z anatomie a kineziologie). Kompetentním se odborník pro realizaci NVS stává absolvováním kurzu NVS, jenž organizačně zajišst́uje INVTS s.r.o. a lektoruje jej Mgr. Marja Volemanová. NVS lze realizovat/aplikovat individuálně i skupinově.

\section{Literatura}

BERNE, S.A.(2006)The Primitive Reflexes:Considerationsin theInfant.Optometry \& VisionDevelopment. 37(3), s. $139-145$.

BEZDĚKOVÁ, J. (2008) Učíme naše dítě mluvit: řečová výchova dítěte od narození do sedmi let. Velké Bílovice: TeMi CZ.

BYTEŠNÍKOVÁ, I. (2012) Komunikace dětí předškolního věku. Praha: Grada.

GANGALE, D. C. (2004) Rehabilitace orofaciální oblasti. Praha: Grada.

GODDARD, S. (2005). Reflexen, leren en gedrag. Zoetermeer: Protocol BV. 
GRZYWNIAK, C. (2016) Role of early-childhood reflexes in the psychomotor development of a child, and in learning. Acta Neuropsychologica. 14(2), s. 113-129.

HURST, C. M. F et al. (2006) Improvements in performance following optometric vision therapy in a child with dyspraxia. Ophthalmic and Physiological Optics. 26(2), s. 199-210.

ILLINGWORTH, R., S. (2012) The development of the infsnt and young children. New

Delphi: Elsevier.

JAGER, M. (2009) Sequence of primitive reflex development. Mind Moves Institute, 2009 [online], [cit. 31.10.2020]. Dostupné z: https://pdfs.semanticscholar.org

KURTZ, L. A. (2015) Hry pro rozvoj psychomotoriky. Praha: Portál.

MCPHILLIPS, M., HEPPER, P. G., MULHERN, G., (2000) Effects of replicating primary-reflex movements on specific reading difficulties in children: a randomised, double-blind, controlled trial. The Lancet. 355(9203), s. 537-54.

STARÁ, M. (1996) Od proního hlasu k proním slovům. Praha: Tech-Market.

VOLEMANOVÁ, M. (2019) Přetruávající primární reflexy. Statenice: INVTS, s.r.o.

VOLEMANOVÁ, M. (2020) Primární reflexy a jejich vliv na motoriku a řeč. Praha: Listy klinické logopedie, 4 (1) s. 37-44.

VYSKOTOVÁ, J., MACHÁČKOVÁ, K. (2013). Jemná motorika, Vývoj, motorická kontrola, hodnocení a testování. Praha: Grada.

\section{Informace o autorech}

\section{Petra Bendová}

Od roku 2006 působí jako odborná asistentka na ÚPPSP PdF UHK. Problematice osob se specifickými potřebami se věnuji již od roku 2003. Zaměřuji se zejména na intervenci o děti i dospělé s narušenou komunikační schopností, specifickými poruchami učení, mentálním postižením, PAS, ADHD, ale i tělesným postižením, sluchovým postižením a kombinovanými vadami. Pracovala ve školském poradenském zařízení (SPC), jako konzultant v Centru pomoci handicapovaným UPOL, dále pak jako logoped v rezortu MŠMT ČR i MZ ČR. Absolvovala několik zahraničních pobytů (Dánsko, Estonsko, Slovensko, Turecko, Polsko), kde měla možnost seznámit se s tamním školským systémem i se specifičností zajištění intervence o osoby se specifickými (zejména vzdělávacími) potřebami v těchto zemích. Je činná v oblasti aktivit vědecko-výzkumného i publikačního charakteru.

Kontaktní údaje:

Telefon: +420 493331391

Email: petra.bendova@uhk.cz 